\title{
PERFORMANCE ANALYSIS OF A DESICCANT EVAPORATIVE COOLING SYSTEM FOR MANGO FRUIT STORAGE IN THE SAVANNAH AND TRANSITIONAL ZONES OF GHANA
}

\author{
Awafo Edward ${ }^{\mathrm{a}^{*}}$, Addo Ahmad ${ }^{\mathrm{b}}$, Bart-Plange Ato ${ }^{\mathrm{b}}$ \\ a Department of Mechanical and Manufacturing Engineering, University of Energy and Natural \\ Resources, Sunyani, Ghana ORCID: 0000-0001-8416-3621 \\ ${ }^{b}$ Department of Agricultural and Biosystems Engineering, Kwame Nkrumah University of Science \\ and Technology, Kumasi, Ghana
}

* Corresponding author: e-mail: edward.awafo@uenr.edu.gh

\begin{tabular}{|c|c|}
\hline ARTICLE INFO & ABSTRACT \\
\hline $\begin{array}{l}\text { Article history: } \\
\text { Received: August } 2019 \\
\text { Received in the revised form: } \\
\text { September } 2019 \\
\text { Accepted: September } 2019 \\
\end{array}$ & $\begin{array}{l}\text { Performance analysis of a } 1.0 \text { tonne desiccant evaporative cooling stor- } \\
\text { age structure for mango fruits was studied. The study examined the ef- } \\
\text { fects of inlet air conditions and water flow rates through an absorber on } \\
\text { the cooling performance of the system. The airflow rate was approxi- } \\
\text { mately } 0.24 \mathrm{~m} 3 \cdot \mathrm{s}^{-1} \text { and water flow rates through the absorber varied }\end{array}$ \\
\hline $\begin{array}{l}\text { Key words: } \\
\text { Mango Storage; } \\
\text { Dehumidification; } \\
\text { Evaporative Cooling; } \\
\text { Ghana }\end{array}$ & $\begin{array}{l}\text { from } 0 \text { to } 0.2521 \cdot \mathrm{s}^{-1} \text {. The system produced approximately } 7 \mathrm{~kW} \text { of cool- } \\
\text { ing at water supply rate of } 0.2521 \cdot \mathrm{s}^{-1} \text {. A simple linear correlation was } \\
\text { established for condition line slope from inlet to exiting air conditions } \\
\text { for all the water flow rates. Lines of best fit resulted in correlation co- } \\
\text { efficient better than } 0.96 \text {. The observed temperatures with a direct evap- } \\
\text { orative cooler, tested with freshly harvested mango fruits were found to } \\
\text { be between } 15.1^{\circ} \mathrm{C} \text { and } 23.4^{\circ} \mathrm{C} \text { and relative humidity between } 81.8 \% \\
\text { and } 97.7 \% \text {. Physiological weight loss and firmness assessments of the } \\
\text { fruits were also conducted. }\end{array}$ \\
\hline
\end{tabular}

\section{Nomenclature}

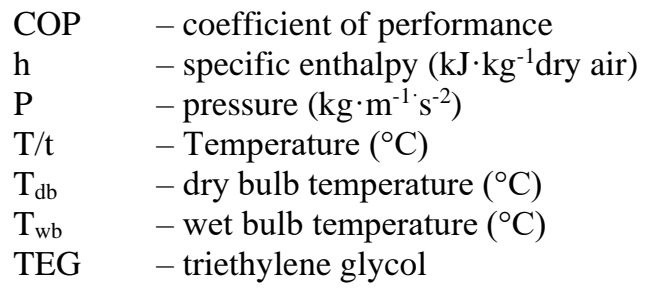

\section{Subscripts}

$\begin{array}{ll}1,2,3,4 & - \text { position/state } \\ \text { A } & - \text { Air state point } \\ \text { a } & - \text { referencing air }\end{array}$




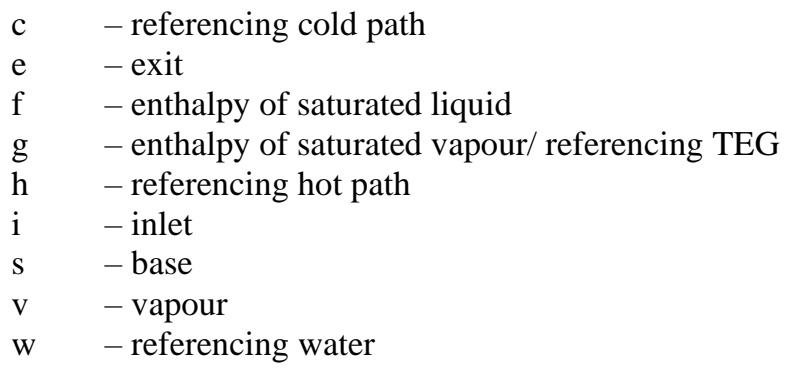

\section{Introduction}

Mango (Mangifera Indica L.) is a very delicious tropical fruit well known for its excellent flavour, attractive fragrance, and nutritional value, and it is usually referred to as the king of fruit (Sivakumar et al., 2011).

Generally, after harvest of fruits, respiration becomes the dominant metabolic activity. Fruits no longer depend on water and minerals absorbed by roots; conduction by vascular tissues and photosynthesis by leaves but survive independently by utilising substrates accumulated during growth and maturation. They consequently ripen and eventually become senescent. These processes lead to changes in colour, tissue permeability, changes in carbohydrate composition, organic acids and protein composition, softening as a 4result of changes in pectic composition, seed maturation, increased respiration and ethylene production.

Metabolism in mango continues even after harvest, and its deterioration rate increases due to ripening, senescence, and unfavourable environmental factors. Due to the highly perishable nature of the fruit, it has short storage life and therefore needs immediate post harvest attention to reduce the microbial load and increase its shelf life. One probable way of doing this is through cold storage. Cold storage results in low temperature and best relative humidity conditions. Hardenburg et al., 1986 states that cold storage retards the following elements of deterioration in perishable produce:

1. aging due to ripening, softening, and textural and colour changes,

2. undesirable metabolic changes and respiratory heat production, and

3. moisture loss and wilting, spoilage due to invasion by bacteria, fungi, and yeasts.

Cold storage methods that are currently being used for fruits storage in most places, especially in developed countries include room icing, forced-air cooling, contact icing, vacuum cooling and hydro cooling. But, mango farmers in Ghana are mainly poor, and live in remote locations which are arid and semi-arid and have no or little access to grid electricity. In view of this, the farmers cannot use these conventional cold storage methods. In such locations, Dash and Chandra (2003) recommends cooling systems that use evaporative cooling principles. Evaporative cooling involves cooling dry air by blowing it across a wet surface; and the conversion of sensible heat to latent heat is the underlying principle of this concept (Camargo et al., 2005). Systems designed using this principle have the advantages of low energy consumption, easy maintenance, simple installation and operation, and are environmentally friendly since water and air are the main working fluids. 
Performance analysis...

In Ghana, mango is mostly grown in the savannah and transitional zones which have wet bulb temperatures between 14 and $27^{\circ} \mathrm{C}$; and the average ambient relative humidity vary between 16 and $77 \%$ throughout the harvest seasons of May - July and December - February (GMSD, 2005). However, the theoretical minimum temperature that can be achieved with a very efficient evaporative cooling system is the wet bulb temperature of the location where the system is used. The storage temperature of most mature mango varieties is $10-15^{\circ} \mathrm{C}$ (Kader et al., 1985). This means that evaporative cooling alone cannot be used in these locations to achieve the required storage temperature.

In order to address this constraint, Awafo (2017) suggests a combined dehumidification and evaporative cooling storage system. A schematic diagram of the system is shown in Figure 2 .

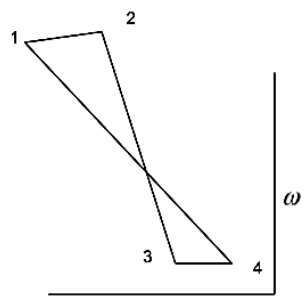

$\mathrm{T}_{\mathrm{db}}$

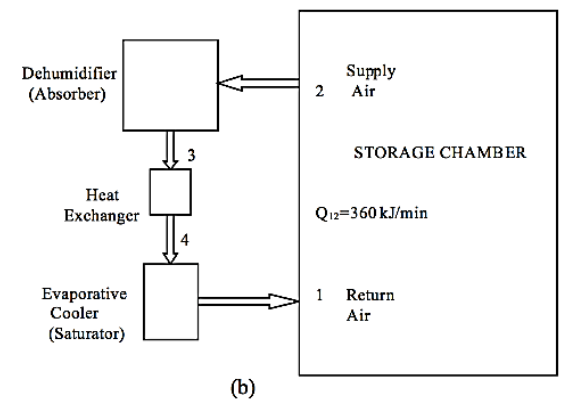

Source: Awafo, (2017)

Figure 2. Flow diagram of combined dehumidification with evaporative cooling: (a) schematic of air process as on a psychrometric chart (b) air flow path

The cooling system consists of four main parts, namely; the storage chamber, dehumidifier [using triethylene glycol (TEG) as desiccant], air -to - air heat exchanger and evaporative cooler (or saturator). From Figure 2, for the (b) part, the air stream at state 2 is passed through a desiccant wheel. The moisture of the airstream at this state is partly but significantly adsorbed by the desiccant material and the heat of adsorption elevates its temperature so that a warm and rather dry air stream exits at the state 3 . The air stream is then cooled successively in the heat exchanger from state 3 to state 4, and then in an evaporative cooler from state 4 to state 1 . At state 1 , the air is much cooler and very moist (lower dry bulb temperature and higher relative humidity) and it is then released into the storage chamber containing the mangoes.

This research was therefore designed to analyse the performance of the experimental storage system, and thus the objective of this paper. The performance analysis is focused on evaluation of the various components of the cooling system and the entire combined unit and its suitability for mango storage in the defined locations.

In order to correlate the data obtained with the experimental combined dehumidification and evaporative cooling system, an active evaporative cooler was constructed with local materials and tested with freshly harvested mango fruits. A schematic of the evaporative cooler is shown in Figure 3. 


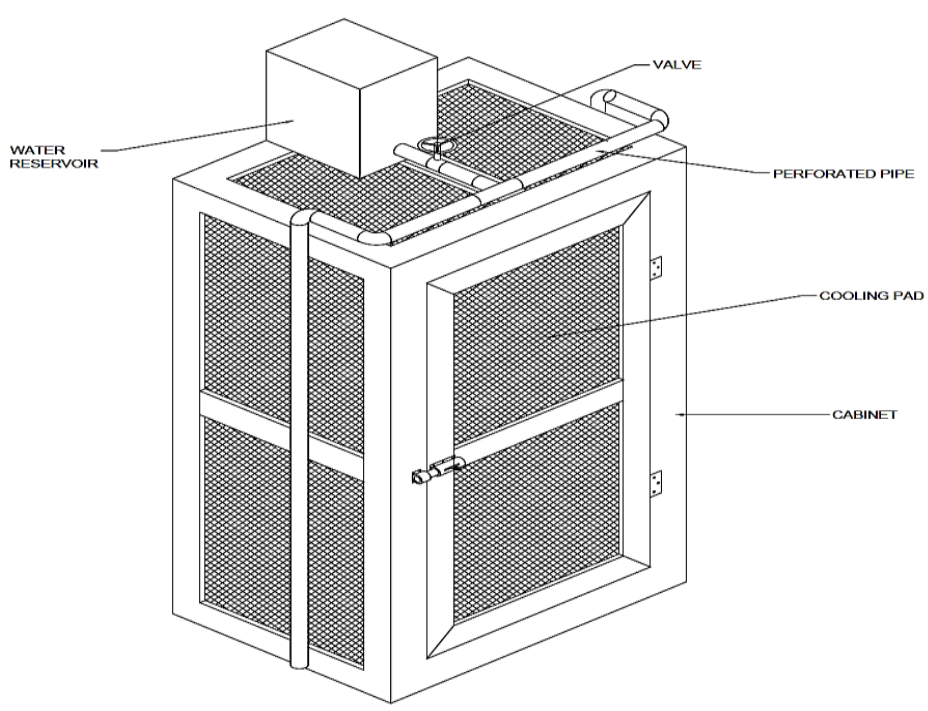

Figure 3. Schematic Diagram of the Evaporative Cooler

The cooler was made with plywood and reinforced with metal mesh. The three surfaces and the door, as well as the top surface were covered with a thin layer of local jute sack materials as the cooling pad. A water reservoir was placed on top of the structure with a perforated pipe connected to it to allow the water run down over all the four surfaces by gravity. The structure was placed in shade under a tree and exposed to ambient air to allow evaporation.

\section{Materials and Methods}

\section{Mathematical models and Design}

The experimental investigation that was carried out tested the capabilities of the various components of the combined cooling system. To analyse the performance of each component, the physical phenomena were qualified with mathematical models. These analytical models have been detailed in Awafo and Dzisi (2012). Also contained in Awafo and Dzisi (2012) is the design of the various components which were assembled as shown in Figure 1 and used for this experimentation.

\section{Instrumentation}

Temperature, pressure, humidity, flow rates, and refractive index were required measurements in this study. Properties of TEG were evaluated using the refractive index and temperature. Properties of air were determined using dry and wet bulb temperature measurements and/or dry bulb temperature and relative humidity measurements. 
Performance analysis...

The instruments that were used to measure the required parameters were mounted on the system and connected to a data logger. Humidity measurements were taken in the incoming and exiting air. Dry bulb temperature measurements were taken before and after the dehumidifier, heat exchanger and evaporative cooler. Wet bulb temperatures were taken after the evaporative cooler and on both sides of the heat exchanger. Water and TEG temperatures were taken entering and exiting the dehumidifier unit. Pressure drop readings were taken before and after the dehumidifier, heat exchanger and evaporative cooler.

\section{Experimental Procedures}

Combined Dehumidification and Evaporative Cooling System

The following experimental procedure was repeated for every experiment. Initially the concentration of the TEG was determined using the refractive index. If the concentration was $98 \% \pm 2 \%$ the experiment was continued. The fan was started to circulate air through the system. The pump to the saturator was turned on and the water flow was adjusted to 0.05 $1 \cdot \mathrm{s}^{-1}$. The water flow through the absorber was set at $0.0,0.063,0.126,0.189$ or 0.252 . The system was allowed to run until the water temperature in the saturator reached a temperature within $1^{\circ} \mathrm{C}$ of the incoming wet bulb temperature of the air. The water entering the absorber was adjusted to this temperature by balancing hot and cold water from the tap until the required water temperature was reached. The system was then allowed to run approximately one and half hours to develop and ensure steady readings.

At this point the data logger was started to record temperatures, pressures and humidity at 5 minutes intervals. After 3 readings without TEG flowing, the TEG pump was started. The TEG was allowed to flow until dehumidification had discontinued. Dehumidification was considered to have reached its limit when the exiting temperature and humidity readings were unchanged for 15 minutes. Total run time of the system was approximately 3 hours. After the system was turned off the TEG was pumped to a regenerator. The regeneration of the TEG usually required three hours of operation. The TEG was then cooled to room temperature for reuse. A total of 41 tests were run and each process took approximately seven hours.

\section{Active Evaporative Cooler}

The tests with evaporative cooler were run under constant water flow rate, pad thickness and varied air velocity.

To determine the cooler's performance, tests were conducted on the length of storage of the mango fruits in the cooler before spoilage and its effects on mango fruits in storage compared with those stored under ambient conditions. A control test in which the same product inside the evaporative cooler was exposed to open-air conditions was used to evaluate the cooler effectiveness in preservation of the green mango fruits.

\section{Results}

This section details the performance characteristics of the evaporative cooling unit, heat exchanger and dehumidifier followed by the performance of the combined system. Data was collected using these inlet conditions: dry bulb temperatures of $20.0^{\circ} \mathrm{C}$ to $36.0^{\circ} \mathrm{C}$, wet bulb temperatures of $14.0^{\circ} \mathrm{C}$ to $25.0^{\circ} \mathrm{C}$ and a water flow rate range of 0.0 to $0.2521 \cdot \mathrm{s}^{-1}$. 
Edward Awafo, Ahmad Addo, Ato Bart-Plange

\section{Saturator}

The saturator was the first piece of equipment constructed and the entire system was designed around the saturator's performance. The saturator was designed to handle a maximum airflow of $0.472 \mathrm{~m}^{3} \cdot \mathrm{s}^{-1}$ at saturation efficiency greater than $95 \%$. The final design varies from the original design only in the number of water distribution tubes used in the header.

The original design of the saturator was first tested in a wind tunnel to establish operating parameters. In the original design the distribution header had five cross tubes to distribute the water. It was found that only the two distribution tubes furthest upstream were necessary to obtain maximum performance. The extra tubes would distribute water too far downstream, on the media, and cause water carry over. Figure 4 demonstrates an assumed water flow through the media.
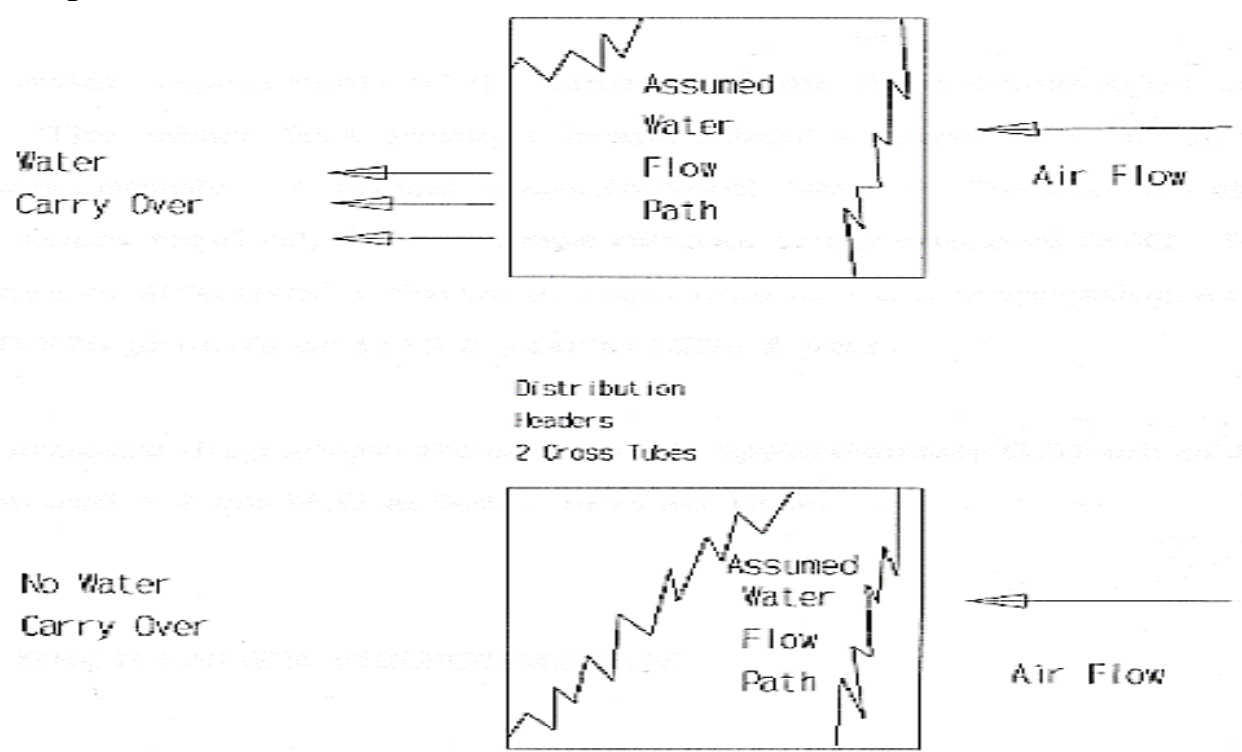

Figure 4. Water Flow Through the Saturator Media due to Injector Locations

The data collected indicates a saturation efficiency of $99 \%$ for the saturator. The expected uncertainty was $\pm 5 \%$ in this calculation. These performance characteristics were maintained with a water flow rate of $0.051 \cdot \mathrm{s}^{-1}$ and a maximum phase velocity of $2.26 \mathrm{~m} \cdot \mathrm{s}^{-1}$, over the various inlet conditions. A maximum water flow rate that could flow through the saturator was $0.126 \mathrm{l} \cdot \mathrm{s}^{-1}$ with air face velocity of $1.13 \mathrm{~m} \cdot \mathrm{s}^{-1}$ or less. Higher air face velocities than those indicated caused water carry over into the air stream.

The water requirements of the saturator come from evaporation and necessary bleed off. The water loss through evaporation is dependent on the amount of humidification possible. For a relative humidity range of $40 \%$ to $60 \%$ the water requirements from evaporation would be $0.413 \mathrm{~g} \cdot \mathrm{s}^{-1}$ to $0.826 \mathrm{~g} \cdot \mathrm{s}^{-1}$ or $1115 \mathrm{l} \cdot$ year $^{-1}$ to $2230 \mathrm{l} \cdot$ year $^{-1}$.

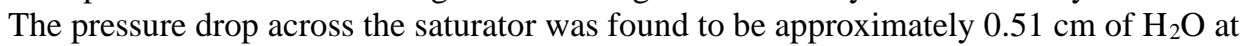
$0.236 \mathrm{~m}^{3} \cdot \mathrm{s}^{-1}$ airflow and $1.2 \mathrm{~cm} \mathrm{H}_{2} \mathrm{O}$ at $0.472 \mathrm{~m}^{3} \cdot \mathrm{s}^{-1}$ airflow. 
Performance analysis...

\section{Heat Exchanger}

The heat exchanger was first tested for cross over contamination before operation. Appendix E shows results of cross over contamination tests. The air pressure of $5.8 \mathrm{~cm}$ of $\mathrm{H}_{2} \mathrm{O}$ was applied to one side of the crossflow heat exchanger. It was determined from the tests that $0.0014 \mathrm{~m}^{3} \cdot \mathrm{s}^{-1}$ would crossover into the next pathway under this pressure difference. Under experimental tests the largest pressure difference between the heat exchanger flow paths is less than $1.3 \mathrm{~cm} \mathrm{H}_{2} \mathrm{O}$. Therefore, contamination is negligible even if the $0.0014 \mathrm{~m}^{3} \cdot \mathrm{s}$ 1 crossed over since it is less than $1 \%$ of the total flow.

The heat exchanger performance was rated by its effectiveness. For balanced mass flow rates between the flow paths and a volume flow rate of $0.236 \mathrm{~m}^{3} \cdot \mathrm{s}^{-1}$, the heat exchanger had an average effectiveness of $0.81 \pm 11.6 \%$. The $\pm 11.6 \%$ possible error indicates sensitivity of the effectiveness calculations. The effectiveness versus the mass flow rate could not be accurately graphed due to this sensitivity. The heat exchanger performance approached $94.4 \%$ for the various tests when the difference in the mass flow rates approached $30 \%$.

The pressure drop through a flow path in the heat exchanger is approximately $0.91 \mathrm{~cm}$ of $\mathrm{H}_{2} \mathrm{O}$ at $0.236 \mathrm{~m}^{3} \cdot \mathrm{s}^{-1}$ and $2.2 \mathrm{~cm} \mathrm{H} \mathrm{H}_{2} \mathrm{O}$ at $0.472 \mathrm{~m}^{3} \cdot \mathrm{s}^{-1}$ of air.

\section{Dehumidifier}

The dehumidifier (absorber) performance was dependent on the air inlet conditions and the water flow rate. The air process that took place in the dehumidifier was influenced by the varying inlet conditions. Figure 5 shows the general effect of water flow in the absorber on the condition line slope for a single inlet condition. The condition line between the inlet state $\mathrm{A}$ and the exit state B, C, D or E represents the possible overall processes that occur in the absorber. For the case of $0.01 \cdot \mathrm{s}^{-1}$ of water flow rate, process A to B, the condition line slope was slightly higher than a line of constant $\mathrm{T}_{\mathrm{wb}}$ in the completed experiments.

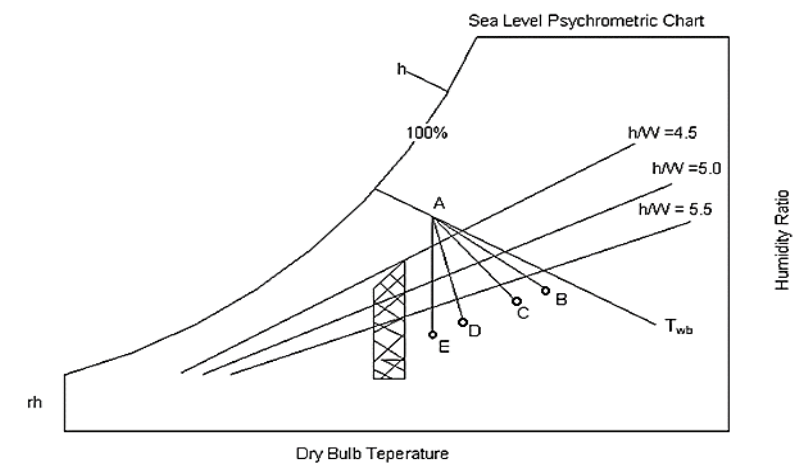

\section{Figure 5. Condition Line Slope and Lines of Constant $h / W$}

Theoretically the condition line should follow a line of the constant wet bulb temperature for the dehumidification process. If a layer of TEG does not come in contact with the air it will only pick up heat conducted into it from the TEG layer reacting with the air. The cooling 
that takes place shifts the condition line below the line of constant inlet air $\mathrm{T}_{\mathrm{wb}}$. Process A to $\mathrm{C}$ was caused by a higher water flow rate at $\mathrm{T}_{\mathrm{wb}}$ of the inlet air than process $\mathrm{A}$ to $\mathrm{B}$. For the water flow rates tested, as the water flow increased the condition line slope increased.

The effectiveness of dehumidification was used to estimate the performance of the absorber.

\section{The Active Evaporative Cooler}

The transient responses of the evaporative cooler with mango fruits stored in it are presented in Figure 6. The graph shows variations of the temperature and relative humidity of the cooler chamber and ambient air with the time of day. These results represent the series of tests undertaken for different times of the day during the 12 days of experimentation.

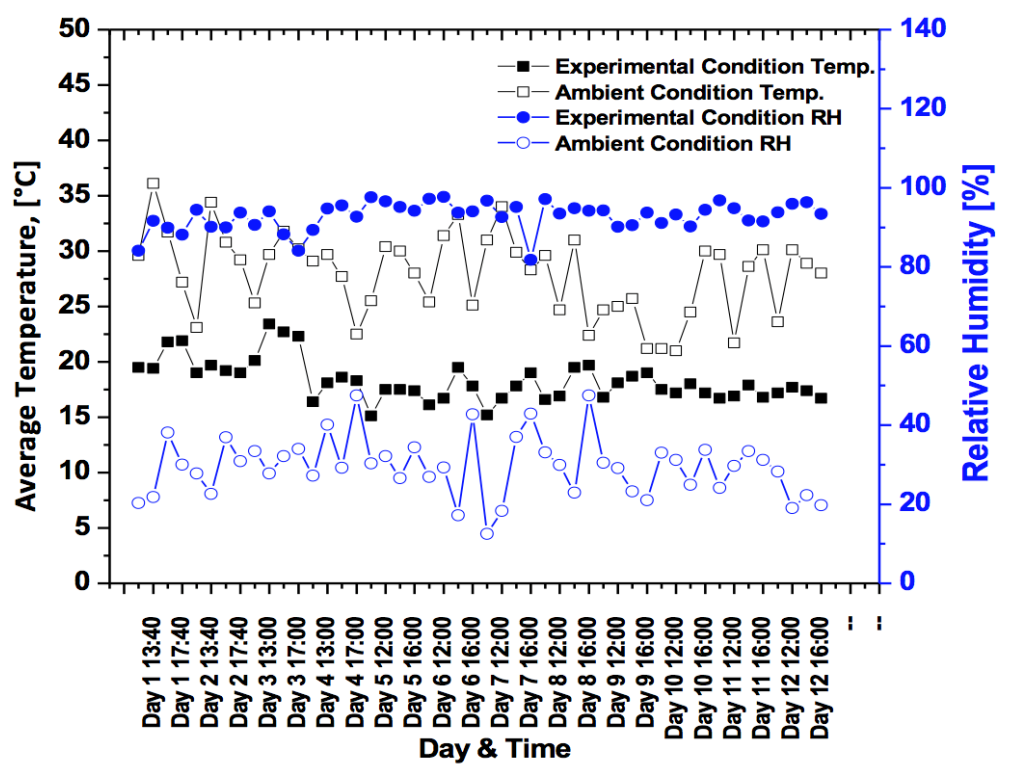

Figure 6. Performance of the Evaporative Cooler

It can be seen from Figure 6 that the cooler chamber temperatures measured were always consistently lower than the ambient air temperatures, with depressions varying over 5.0$3.0^{\circ} \mathrm{C}$. The results also showed better performance of the cooler between 13 and 18 hours with temperature depressions between 6 and $12^{\circ} \mathrm{C}$ most of the time. The diurnal ambient relative humidity levels below $50 \%$ at these hottest times of the day, consistent with the literature, are well within the levels necessary to facilitate effective evaporative cooling. The ambient relative humidity profile during tests was very irregular, and this is largely attributable to the prevailing varying wind speeds. It was seen that high ambient air temperatures corresponded to low relative humidity and vice versa. 
Performance analysis...

\section{Discussion}

\section{Overall system performance}

Typical system processes can be seen in Figure 7 (state points a, b, c, d and e). State b is the result of adiabatic saturation of inlet state a. State $d$ is created by the heat exchange between states $a$ and $b$. State $e$ is the result of dehumidification and cooling of state $d$.

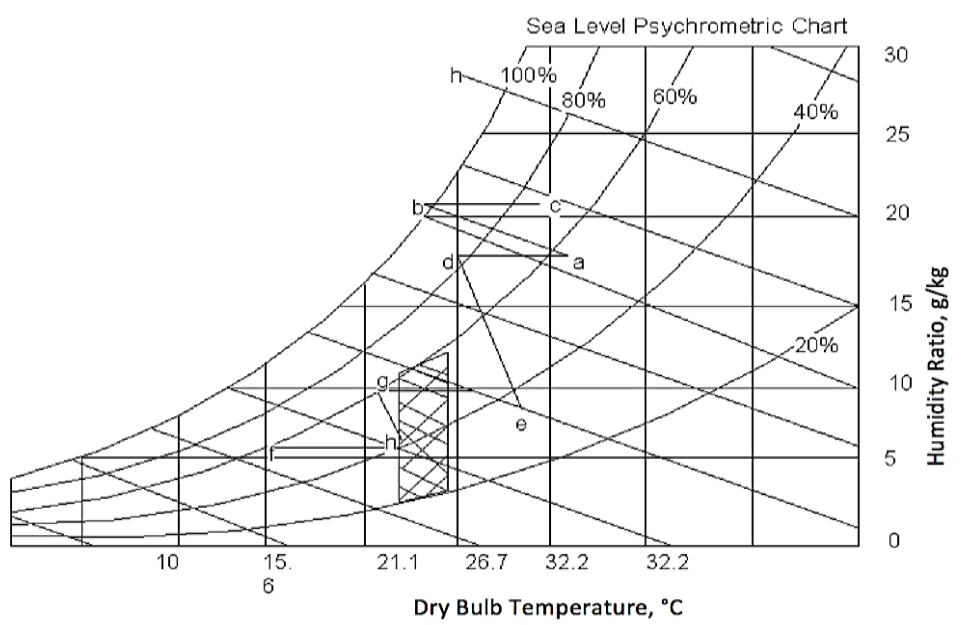

Figure 7. Typical System Performance (Single Test Results)

Figure 8 shows the cooling performances of the system, which were constructed by linearly interpolating between the tested inlet and exit conditions to points with properties corresponding to $\mathrm{h} / \mathrm{W}=4.5 \mathrm{~kJ} \cdot \mathrm{kg}^{-1}, 5 \mathrm{~kJ} \cdot \mathrm{kg}^{-1}$ and $5.5 \mathrm{~kJ} \cdot \mathrm{kg}^{-1}$. The inlet conditions along $\mathrm{h} / \mathrm{W}=4.5$ $\mathrm{kJ} \cdot \mathrm{kg}^{-1}$ produce higher cooling outputs than does inlet conditions along $\mathrm{h} / \mathrm{W}=5.5 \mathrm{~kJ} \cdot \mathrm{kg}^{-1}$.



Figure 8. Effect of Dry Bulb Temperature on Cooling Performance for $0.252 l \cdot s^{-1}$ Water Flow through the Absorber 
Condition lines from the inlet state to the exit state, for the overall system are illustrated in Figure 9.

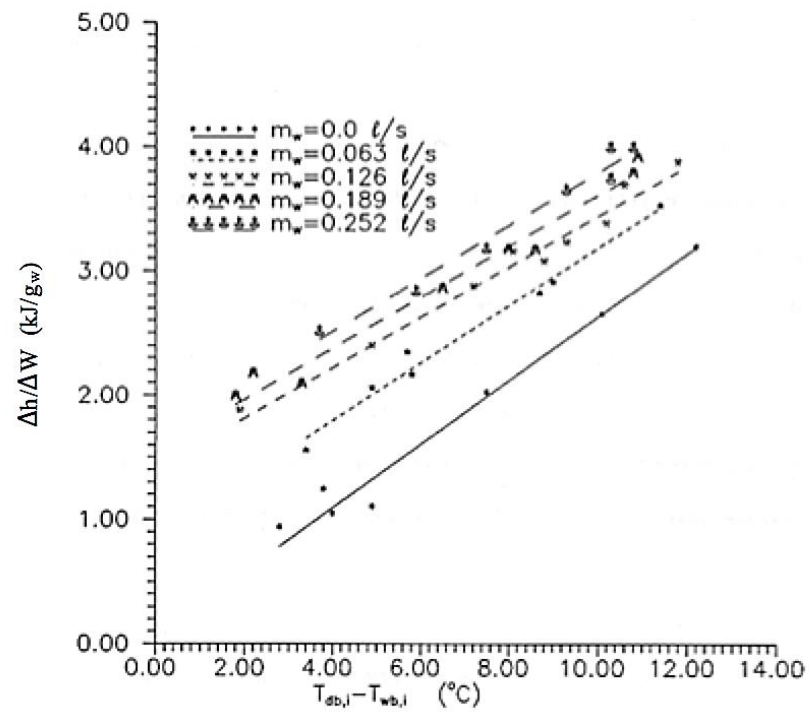

Figure 9. Overall System Condition Line Slope from Inlet to Exiting Conditions

A linear correlation between $\mathrm{T}_{\mathrm{db}, \mathrm{i}}-\mathrm{T}_{\mathrm{wb}, \mathrm{i}}$ and condition line slope was established for the various flow rates:

$$
\begin{aligned}
& 0.000 l / s y=0.248 x+0.138 \text { Eqn. (1) } \\
& 0.063 l / s y=0.231 x+0.870 \text { Eqn. (2) } \\
& 0.126 l / s y=0.200 x+1.150 \text { Eqn. (3) } \\
& 0.189 l / s y=0.202 x+1.585 \text { Eqn. (4) } \\
& 0.252 l / s y=0.216 x+1.643 \text { Eqn. (5) }
\end{aligned}
$$

These lines of the best fit were established by the least squares fit, which resulted in the correlation coefficient, $R^{2}$, better than 0.96 .

The estimated COP of the system ranged from 0.022 at $0.01 \cdot \mathrm{s}^{-1}$ to 1.29 at $0.2521 \cdot \mathrm{s}^{-1}$ water flow at airflow of $0.236 \mathrm{~m}^{3} \cdot \mathrm{s}^{-1}$.

\section{Overall Cooler Performance and Effects on Mango Quality}

Quality assessment of the mango fruits stored inside the cooler compared to those stored under ambient conditions was also carried out. This quality assessment based on the AOAC (1984) methods, were changes in firmness and physiological weight loss.

\section{Fruit Firmness Changes}

The results for the mango fruit firmness change stored under both the evaporative cooler and ambient conditions are presented in Figure 10. Fruit firmness changes were observed 
Performance analysis...

more under ambient conditions, especially after day 3. Fruit firmness change is a biochemical change, which occurs during the ripening process. Generally, fruit ripening is accelerated at high temperatures (Wills et al., 1981). This explains the significant change in fruit firmness for the fruits stored under ambient conditions, which is at higher temperatures than those of the evaporative cooler.

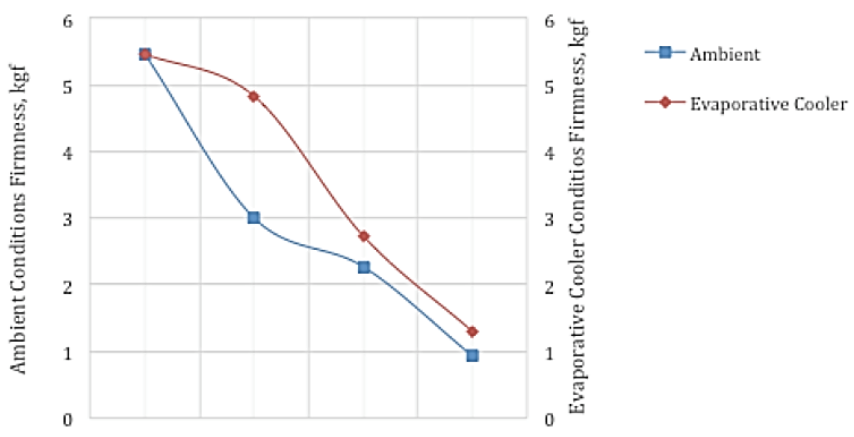

Figure 10. Firmness of Fruits Stored in the Cooler Compared to those Stored under Ambient Conditions

Physiological Weight Loss of Stored Mango Fruits

The results of the physiological weight loss for the mango fruits stored under both ambient condition and in the evaporative cooler are presented in Figure 11.

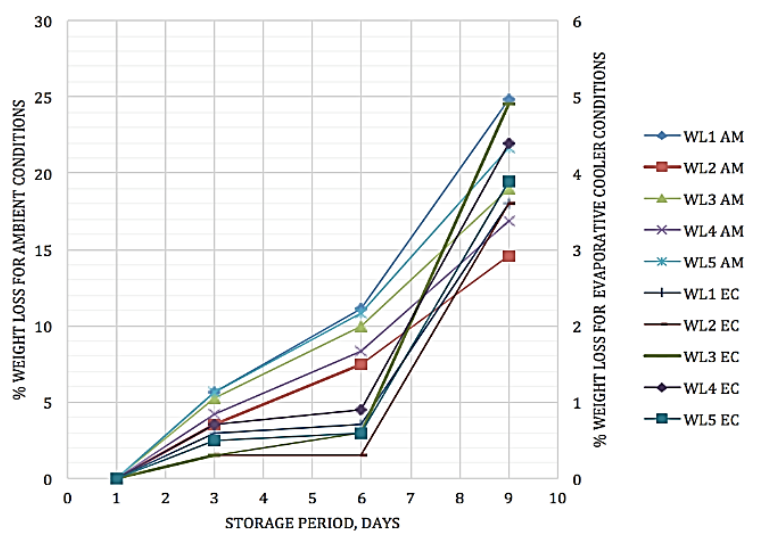

Figure 11. Physiological Weight Loss for Mango Fruits Stored in the Cooler Compared to those Stored Under Ambient Conditions.

The fruits stored in the evaporative cooler had lower physiological weight loss compared to those stored in the ambient conditions. The trend in the physiological weight loss in the 
cooler was similar for all the produce without any sharp increase in the percentage weight loss. Under ambient conditions, the produce showed a sharp increase in the weight loss after 3 days of storage compared to those stored in the evaporative cooler.

Physiological loss in weight of the fruits is due to both evaporation of water and respiratory losses. Evaporation of water from the produce and the respiratory losses are dependent on the temperature and relative humidity of the air surrounding the produce. Low temperature reduces the respiratory activity and high relative humidity reduces the rate of evaporation from the produce. The slight losses in weight of the fruit recorded in the evaporative cooler with the average storage condition of $18^{\circ} \mathrm{C}$ and $92.8 \%$ temperature and relative humidity, respectively could therefore be attributed to the low temperature and high relative humidity in the evaporative cooler.

High loss in weight for the ambient storage could also be attributed to the high temperature and low relative humidity, averaging $28^{\circ} \mathrm{C}$ and $29.5 \%$ respectively. The average differences in dry bulb temperature between ambient and inside the cooler was $10^{\circ} \mathrm{C}$, with the average difference in relative humidity of $63.3 \%$ during the 12 days of storage.

\section{Conclusion}

The saturator proved to provide high saturation efficiencies from $80-100 \%$ with low blower requirements of approximately $1.2 \mathrm{~cm} \mathrm{H}_{2} \mathrm{O}$ at $0.472 \mathrm{~m}^{3} \cdot \mathrm{s}^{-1}$. The saturation unit is easy to operate and the material costs for construction are minimal. Although, it is efficient and cheap to build, water requirements range from $11151 \cdot$ year $^{-1}$ to $22301 \cdot$ year $^{-1}$. Also, the water may require regular replacement or treatment to allow long term usage of the equipment.

The air-to-air heat exchanger operated at approximately $80 \%$ efficiency. The heat exchanger was dimensionally larger than the saturator to accommodate the airflow and maintain heat exchange efficiency. The blower requirements were maintained at a relatively low value of $2.2 \mathrm{~cm} \mathrm{H}_{2} \mathrm{O}$ at $0.472 \mathrm{~m}^{3} \cdot \mathrm{s}^{-1}$ airflow.

The combination of the saturator and heat exchanger was used to eliminate the primary sensible and latent loads in the storage structure. Air at $30^{\circ} \mathrm{C}$ dry bulb and $23^{\circ} \mathrm{C}$ wet bulb, can be cooled to below $12^{\circ} \mathrm{C}$ dry bulb in the storage structure while maintaining the humidity ratio.

The absorber effectiveness ranged from $44.4 \%$ to $96 \%$ depending on the inlet air condition. The absorber represented the largest power requirements of all the components. The blower requirements were $8.9 \mathrm{~cm} \mathrm{H}_{2} \mathrm{O}$ at $0.236 \mathrm{~m}^{3} \cdot \mathrm{s}^{-1}$ airflow. It also requires a TEG sprayer pump and a cooling tower pump. The absorber cooling tower size requirements for $0.1261 \cdot \mathrm{s}^{-1}$ water flow is the same size as the saturator.

Triethylene glycol operated effectively in dehumidifying the air. The main TEG loss came through leaks in the pump system. Although not shown, another possible loss comes from TEG being carried out with the air stream.

A computer simulation programme was written using FORTRAN codes. The programme was used to evaluate the required volume of the cooling tower of the saturator and, it also accurately determined the air temperatures and conditions at the various states and water temperatures. Three key assumptions were made in solving the model with the simulation programme, namely; no heat transfer through the walls, no water loss by drift and steady flow 
Performance analysis...

conditions. The accuracy of the programme depended on the size of the incremental changes in the air state when arbitrarily locating state two.

For the active evaporative cooler, the tests were conducted under the constant water flow rate of $0.236 \mathrm{~m}^{3} \cdot \mathrm{s}^{-1}$, pad thickness of $5 \mathrm{~mm}$ made from jute sacks and varied air velocity. The storage using evaporative cooling maintained temperatures between $15.1^{\circ} \mathrm{C}$ and $23.4^{\circ} \mathrm{C}$ nd relative humidity between $81.8 \%$ and $97.7 \%$ compared with temperatures varying from 21 $36.1^{\circ} \mathrm{C}$ and relative humidity of $12.5-47.5 \%$ for ambient conditions, respectively, during storage periods under savannah harmattan conditions. The temperature and relative humidity observed in the cooler correlate well with the performance of the combined dehumidification evaporative cooling unit, which had the capacity to reduce cooling in the structure to $12^{\circ} \mathrm{C}$.

The achieved storage temperature greatly influenced the postharvest quality parameters monitored, namely physiological weight loss and firmness change, which significantly improved the shelf life of the mango fruits and no visible damage to the mango fruits up to the $12^{\text {th }}$ day.

\section{References}

AOAC (1984). Official methods of analysis (13th edition). Association of Official Analytical Chemists, Washington D.C.

Awafo, E.A. (2017). Design and Performance Analysis of a Combined Dehumidification and Evaporative Cooling System for Mango Storage in the Transitional and Savannah Zones of Ghana [PhD Thesis]. Kwame Nkrumah University of Science and Technology, Ghana.

Awafo, E.A., Dzisi, K.A. (2012). Analytical Models and Design of Combined Dehumidification and Evaporative Cooling System for Mango Storage in Ghana. International Journal Current Research Review, 4(20), 177-187

Camargo, J.R., Ebinuma, C.D., Siveria, J.L. (2005). Experimental performance of a direct evaporative cooler operating during summer in Brazilian city. International Journal of Refrigeration, 28,11241132 .

Dash, S.K., Chandra, P. (2003). Computer Simulation of the Environment of Evaporatively Cooled Storage Structure. Journal of the Institution of Engineers (India): Agricultural Engineering Division, 84(1), 33-38.

GMSD. (2005). Annual climatic data of Ghana. Ghana Meteorological Services Department (GMSD), Accra, Ghana.

Hardenburg, R.E., Watada, A.E., Wang, C.Y. (1986). The commercial storage of fruits, vegetables, and florist and nursery stocks. United States Dept. Agri. Handbook 66.

Kader, A.A., Kasmire R.F., Mitchell, F.G., Reid, M.S., Sommer, N.F., Thompson, J.F. (1985). Postharvest technology of horticultural crops. California Cooperative and Extension Services. Series 3311

Sivakumar, D., Jiang, Y. and Yahia, E.M. (2011). Maintaining mango (Mangifera indica L.) fruit quality during the export chain. Food Research International, 44, 1254-1263

Wen Q., Ma R., Dong Q. and Xin, Y. (2006). Studies on postharvest physiology and the storage technology of mango (Mangifera indica L.). Journal of Food Processing and Preservation, 30, 670683.

Wills, R.H.H., Lee, T.H. Graham, D., McGlasson, W.B., Hall, E.G. (1981). Post-Harvest: An Introduction to the Physiology and Handling of Fruit and Vegetables. Granada Publishing Co. 


\section{ANALIZA WYDAJNOŚCI SYSTEMU POŚREDNIEGO CHLODZENIA WYPARNEGO DO PRZECHOWYWANIA OWOCÓW MANGO NA SAWANACH I W STREFACH PRZEJŚCIOWYCH GHANY}

Streszczenie. Artykuł omawia analizę wydajności chłodni wyparnej o poj. 1,0 tony, wykorzystywanej do przechowywania owoców mango. Zbadano wpływ warunków wlotowych powietrza i szybkości przepływu wody przez pochłaniacz na wydajność chłodniczą systemu. Natężenie przepływu powietrza wynosiło około $0,24 \mathrm{~m}^{3} \cdot \mathrm{s}^{-1}$, a natężenie przepływu wody przez absorber wahało się od 0 do $0,2521 \cdot \mathrm{s}^{-1}$. W tym czasie wyprodukowano około $7 \mathrm{~kW}$ chłodu przy przepływie wody wynoszącym $0,252 \mathrm{l} \cdot \mathrm{s}^{-1}$. Określono prostą korelację liniową nachylenia linii wykresu warunków, od wlotu do wylotu powietrza, dla wszystkich wielkości przepływu wody. Linie o najlepszym dopasowaniu dały współczynnik korelacji powyżej 0,96 . Zaobserwowane temperatury chłodni wyparnej, sprawdzane na świeżo zebranych owocach mango, wynosiły od $15,1^{\circ} \mathrm{C}$ do $23,4^{\circ} \mathrm{C}$, a wilgotność względna od $81,8 \%$ do $97,7 \%$. Dokonano również oceny fizjologicznej utraty masy i jędrności owoców.

Słowa kluczowe: przechowywanie mango, osuszanie, chłodzenie wyparne, Ghana 